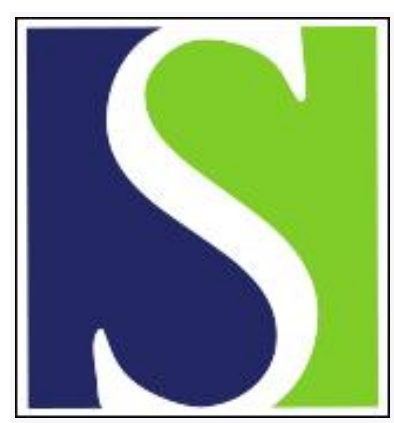

Scand J Work Environ Health 1985;11(4):311-316

https://doi.org/10.5271/sjweh.2224

Issue date: Aug 1985

Testing for mutagens in filter samples from the work atmosphere of an aluminum plant.

by Krokje A, Tiltnes A, Mylius E, Gullvag B

This article in PubMed: www.ncbi.nlm.nih.gov/pubmed/3903983

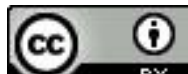




\title{
Testing for mutagens in filter samples from the work atmosphere of an aluminum plant
}

\author{
by Åse Krøkje, MSc, ${ }^{1}$ Arne Tiltnes, MSc, ${ }^{2}$ Erling Mylius, MD, ${ }^{3}$ Barbro Gullvåg, $\mathrm{PhD}^{1}$
}

\begin{abstract}
KRØKJE Å, TILTNES A, MYLIUS E, GULLVÅG B. Testing for mutagens in filter samples fromthe work atmosphere of an aluminum plant, Scand J Work Environ Health 11 (1985) 311-316. Filter extracts of airborne particles from a Söderberg potroom and an anode paste plant were tested for mutagenicity by the Salmonella reversion assay. The extracts were mutagenic to strains TA100 and TA98, mainly after metabolic activation, but positive results were obtained also without S9 mix in strain TA98. These findings indicate that the particulate phase of air from the potroom and the anode paste plant of aluminum plants contain mostly indirect mutagens of both the base-pair substitution and frameshift type, and - to a less degree - direct frameshift mutagens. The relationship between concentration and mutagenicity was more positive for the potroom extract than for the anode paste plant extract.
\end{abstract}

Key terms: polycyclic aromatic hydrocarbons, primary aluminum plant, Salmonella typhimurium.

No entirely error-free method exists by which to test the mutagen load on the human body from inhaled pollution. Chemical and physical analysis of the atmosphere of the workplace can form an initial step in this direction. The 1ext step can be to test the mutagenicity of filter samples of the air. The Salmonella mutagenicity test has been used for investigating the mutagenic potential of extracts, and fractions of extracts, of the particulate matter from air pollution in internal and external environments (4). Particulates can act as carriers for those types of mutagens which may be eluated by body fluids or cellular membranes. Some investigators $(5,12,14)$ have tried to evaluate the biological availability of the mutagens by using serum or saline solutions as solvents instead of organic ones. We have approached this question by using the Salmonella typhimurium test on filter samples and on samples of expectorate (10) and urine (9) from exposed workers.

The incidence of lung cancer is higher among workers in Söderberg-type aluminum plants than among the general population (6). Chemical exposure in an aluminum plant of this kind is complex (unpublished report of J Rob) and comprises relatively high concentrations of polycyclic aromatic hydrocarbons (PAH). Chemical measurements have shown that the PAH concentrations vary between 4 and $4150 \mu \mathrm{g} / \mathrm{m}^{3}$ in the potroom and between 5 and $1200 \mu \mathrm{g} / \mathrm{m}^{3}$ in the anode paste plant (3).

In the present study, we report results of mutagenicity studies on air samples from a Söderberg pot-

\footnotetext{
1 Department of Botany, Section for Cell Biology, The University of Trondheim, Norway.

2 The Labour Inspection, Drammen, Norway.

3 Department of Pathology, University Hospital of Trondheim, Norway.
}

Reprint requests to: Ms $\AA$ Krøkje, Department of Botany, Section for Cell Biology, The University of Trondheim, N-7055 Dragvoll, Norway. room and an anode paste plant. These two kinds of workplaces were specifically chosen because their PAH compositions and concentrations differ.

\section{Materials and methods}

Aluminum is produced by the electrolysis of alumina dissolved in a melt consisting mainly of a mixture of aluminum fluoride $\left(\mathrm{AlF}_{3}\right)$ and cryolite $\left(\mathrm{Na}_{3} \mathrm{AlF}_{6}\right)$. The electrolysis takes place in the potroom where carbon-lined pots serve as cathodes and are maintained at approximately $970^{\circ} \mathrm{C}$ by electrical resistance to the current passing between the cathode and a carbon anode suspended in the bath. Anode paste is supplied from the paste plant. Airborne particles from the potroom $(\mathrm{P})$ and the anode paste plant $(\mathrm{A})$ were collected on Acropore filters (AN-800, diameter $37 \mathrm{~mm}$ ) connected to a Casella pump. The pump was situated beside the crane-bridge in the potroom and over the mixing machine in the anode paste plant. Unlike a worker in an aluminum plant, the sampling device was stationary. The sampling rate was about $21 / \mathrm{min} ; 30$ filters were exposed in each workplace (94-155 l/filter). Unexposed filters (F) were used as controls.

The following chemicals were used during the preparation work: cyclohexane, analytical purity (Merck); dimethylsulfoxide (DMSO), spectrometric grade (Merck); 2-aminoanthracene, practical grade (Sigma); benzo(a)pyrene, practical grade (Sigma); nutrient broth no 2 (Oxoid Ltd); Bacto-Agar (Difco); L-histidin - hydrogen chloride (Sigma); d-biotin (Sigma); Vogel Bonner Minimal "E" Agar-plates (Gibco Bio-cult); S9 (Litton Bionetics, United States); glucose-6-phosphate (Sigma); nicotinamide adenine dinucleotide phosphate (NADP) (Sigma).

The particle samples were obtained by ultrasonic treatment of the Acropore filters, by a modifica- 
tion of Tøgersen's method (15). The filters were extracted ultrasonically for $30 \mathrm{~min}$ in a solution of $96 \%$ ethanol. Two and two filters were treated together with $5 \mathrm{ml}$ of ethanol. The extraction with ethanol $(5 \mathrm{ml})$ was repeated for $15 \mathrm{~min}$. The two ethanol extracts were pooled, and $5 \mathrm{ml}$ of cyclohexane and $10 \mathrm{ml}$ of water were added and then extracted ultrasonically for a further $30 \mathrm{~min}$. The cyclohexane was removed and the aqueous phase was extracted with cyclohexane $(5 \mathrm{ml})$ once more for $15 \mathrm{~min}$. The combined cyclohexane extracts were stored in dark bottles in a refrigerator.

In each experiment the cyclohexane extract was evaporated to dryness at $50^{\circ} \mathrm{C}$ in an atmosphere of pure nitrogen. When drying was complete, DMSO was added to dissolve the cyclohexane residue. The resulting solution was used for the test. The loaded filters were shaded from the light during handling. The control filters were treated in exactly the same way as the exposed filters.

For the unexposed filters $100 \mu \mathrm{l}$ of stock solution corresponds to $1.25 \mathrm{ml}$ of cyclohexane extract. The stock solution was diluted with DMSO to obtain concentrations of $0.05,0.25,0.5$, and $1.0 \mathrm{ml}$ of cyclohexane extract per $100 \mu \mathrm{l}$ of test solution.

For the filter samples from the anode paste plant $100 \mu \mathrm{l}$ of stock solution corresponds to $1.35 \mathrm{ml}$ of cyclohexane extract and $61.1 \mathrm{l}$ of air. This stock solution was diluted with DMSO to obtain test concentrations corresponding to $2.0,5.0,10.2,20.4,40.0$, and $61.1 \mathrm{l}$ of air per $100 \mu \mathrm{l}$ of test solution.

For the filter samples from the potroom $100 \mu \mathrm{l}$ of stock solution corresponds to $1.17 \mathrm{ml}$ of cyclohexane extract and $56.6 \mathrm{I}$ of air. This stock solution was diluted with DMSO to obtain test concentrations corresponding to $1.9,5.0,9.4,18.8,37.7,40.4$, and $56.5 \mathrm{l}$ per $100 \mu \mathrm{l}$ of test solution.

The $S$ typhimurium strains TA98 and TA100 were kindly supplied by Dr BN Ames, Berkeley, United States. The mutagenesis assay was carried out as described by Ames et al (2). Tests were carried out in the presence and absence of S9 mix (50 $\mu \mathrm{l} \mathrm{S9/plate,}$ S9 from Aroclor-induced male Sprague-Dawley rats with cofactors). The relationship between the concentration and the effect of the extracts from the unexposed filters was tested at four different concentrations (duplicate plates). In a preliminary experiment, the extracts from the exposed filters (both $\mathrm{P}$ and $\mathrm{A}$ ) were tested at six different concentrations (triplicate plates) to establish the relationship between concentration and effect. Where this relationship was found to be approximately linear, two of these concentrations were chosen for use in a further experiment. The two concentrations chosen were 5 and 401 of air. They were then investigated with the use of TA98+/-S9 and TA100+/-S9 in five parallel petri plates. Each test was duplicated, in independent experiments, to ensure reproducibility. The statistical significance of all the results was tested by the Student's t-test $(7,18)$, the results of the independent tests being presented separately. In each experiment five parallel petri plates, with bacteria only in the top agar, were used as a check on the spontaneous frequency of mutations and of the physiological state of the bacteria. Another five to eight parallel petri plates, with DMSO or DMSO + S9 mix combined with bacteria in the top agar, were used as controls. Checks on the activating capacity of the S9 mix were made in each experiment, with $2.5 \mu \mathrm{g}$ of 2 -aminoanthracene or $1 \mu \mathrm{g}$ of benzo(a)pyrene. Two parallel petri plates were used with each strain. On the assumption that the number of bacteria able to produce revertants is the same for the test-solution plates as for the control plates, the net yield response $\left(R_{N}\right)$ can be estimated from the difference between the number of revertants on the test plates $\left(R_{T}\right)$ and the control value of the solvent $\left(R_{K}\right)$ as

$$
R_{N}=R_{T}-R_{K} \text {. }
$$

The results were regarded as positive when the following criteria were fulfilled: reproducibility, positive relationship between the concentration of the test solution and its effect, statistical significance, and a twofold increase in the number of revertants compared to the spontaneous number (13).

We chose to evaluate $R_{T}$ against the respective $R_{K}$ values for the concentrations of the test solutions which fell within the linear range of the concentration-effect relationship and which were based on the results from five parallel agar plates.

\section{Results}

The activity of the $\mathrm{S} 9 \mathrm{mix}$ was confirmed with the positive controls. The net response $\left(\mathrm{R}_{\mathrm{N}}\right)$ with $2.5 \mu \mathrm{g}$ of 2-aminoanthracene was 1500-2 100 (TA98+S9) and $1200-1800$ (TA100+S9), and with $1 \mu \mathrm{g}$ of benzo(a)pyrene 218.4 (TA98+S9) and 407.6 (TA100+ S9).

\section{Unexposed filters}

The results from the unexposed filters showed no indication of a concentration-effect relationship (figure 1), nor did cyclohexane, or any other of the chemical substances, have any effect on the bacteria.

\section{Anode paste plant}

The air from the anode paste plant had a mutagenic effect on both bacterial strains (figure 1). Without S9 mix, a weak correlation was obtained between concentration and effect for the TA98 strain. The results for the 40-1 sample of air also indicated a mutagenic effect, suggesting that some direct frameshift type of mutagens really were present (figure 2). With S9 activation, a positive relationship existed between concentration and $R_{N}$ for both bacterial strains. A weak response was shown for the 5-1 sample, and a very 

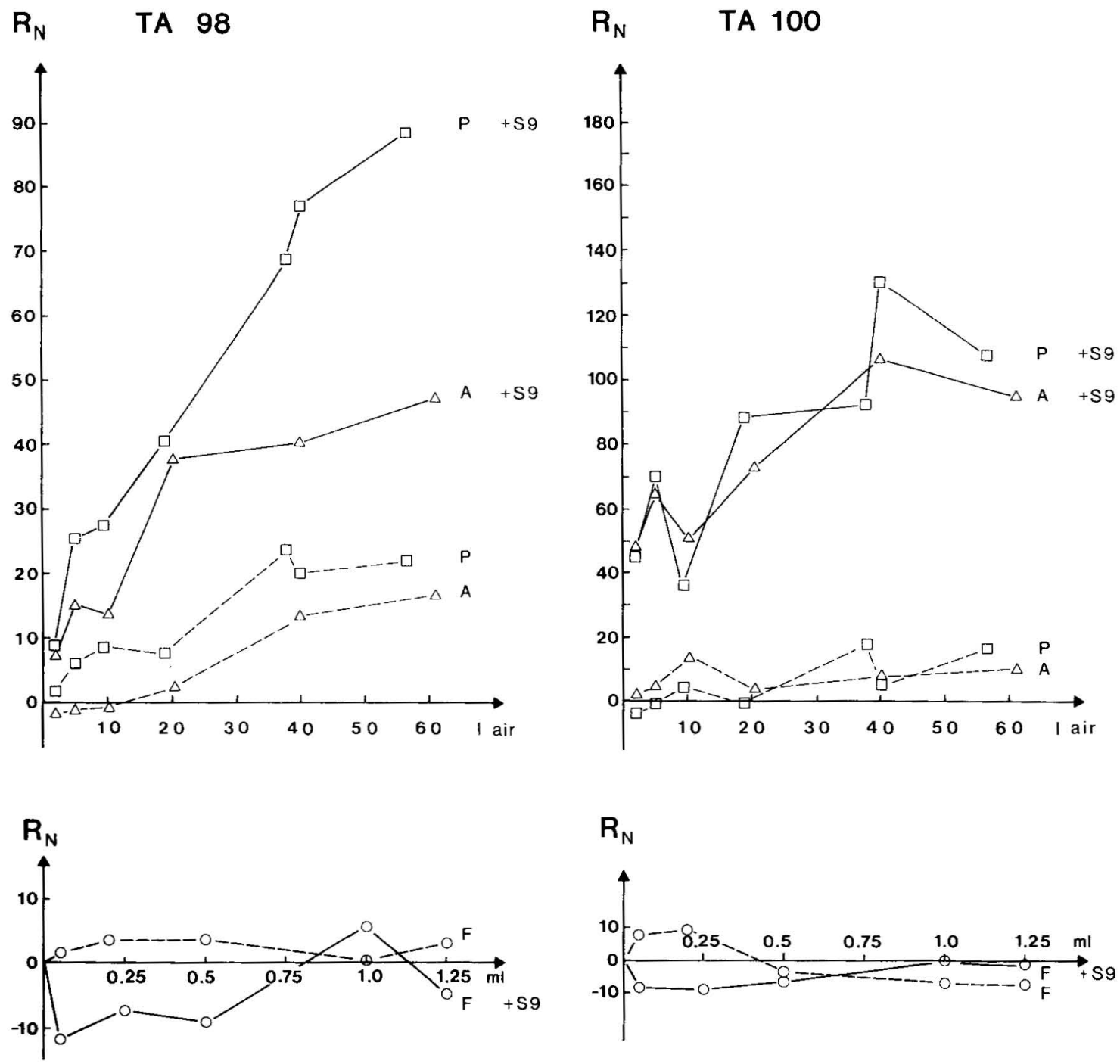

Figure 1. Mutagenic effects of the extracts of airborne particulates from the atmosphere in the anode paste plant $(A)$ and the potroom $(P)$ and of those from unexposed Acropore filters $(F)$. The concentrations for $A$ and $P$ are expressed as liters of air per plate, whereas for $F$ they are expressed as milliliters of cyclohexane per plate. The net responses $\left(R_{N}\right)$ of the bacteria after $48 \mathrm{~h}$ of incubation are shown. For some of the concentrations each data symbol represents the mean of the $R_{N}$ values for two or more independent experiments.

clear effect was seen for the 40-1 sample with both strains of the bacteria (figure 2).

\section{Potroom}

The particulate extract from the potroom had a mutagenic effect on both strains (figure 1). Without activation the correlation between concentration and response in TA98 was weakly positive. The 40-1 sample of air had a mutagenic effect on TA98 (figure 2). A strong increase in mutagenicity was found in the presence of metabolic activation. The relationship between concentration and effect was clearly positive, and the correlation for the TA98 strain was linear (linear correlation coefficient $(r)=0.97)$. Even the 5-1 sample of air yielded a mutagenic effect with both strains of bacteria (figure 2).

The extracts of airborne particulate matter from the potroom and the anode paste plant had about the same effect on strain TA100, with or without S9 activation (figure 1). When strain TA98 was used, the particulate matter in the potroom atmosphere had a greater degree of mutagenic activity than that from the anode paste plant. With activation, the difference was significant $(\mathrm{p}<0.001)$ for both the $5-1$ and the 40-1 samples of air. The relationship between concentration and effect was more positive for the potroom extract than for the anode plant extract. 

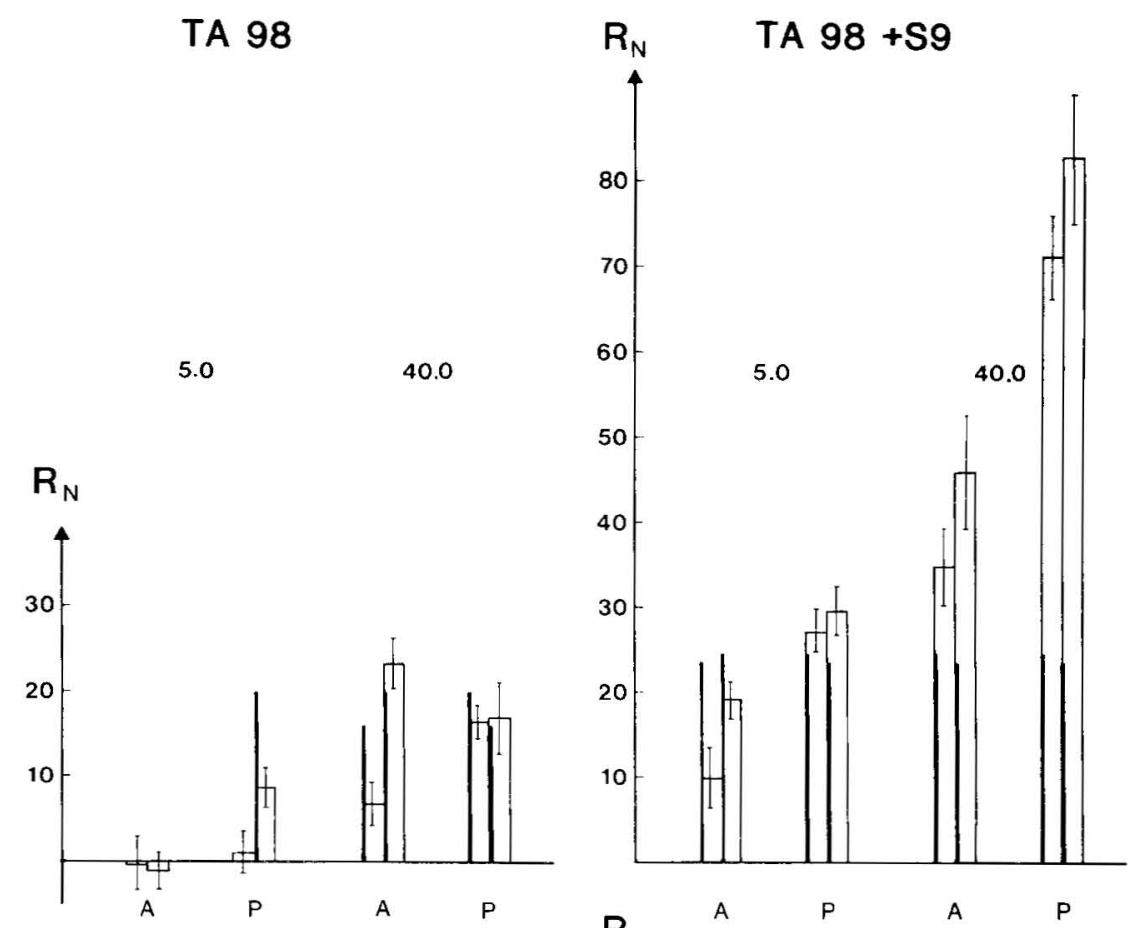

TA 100
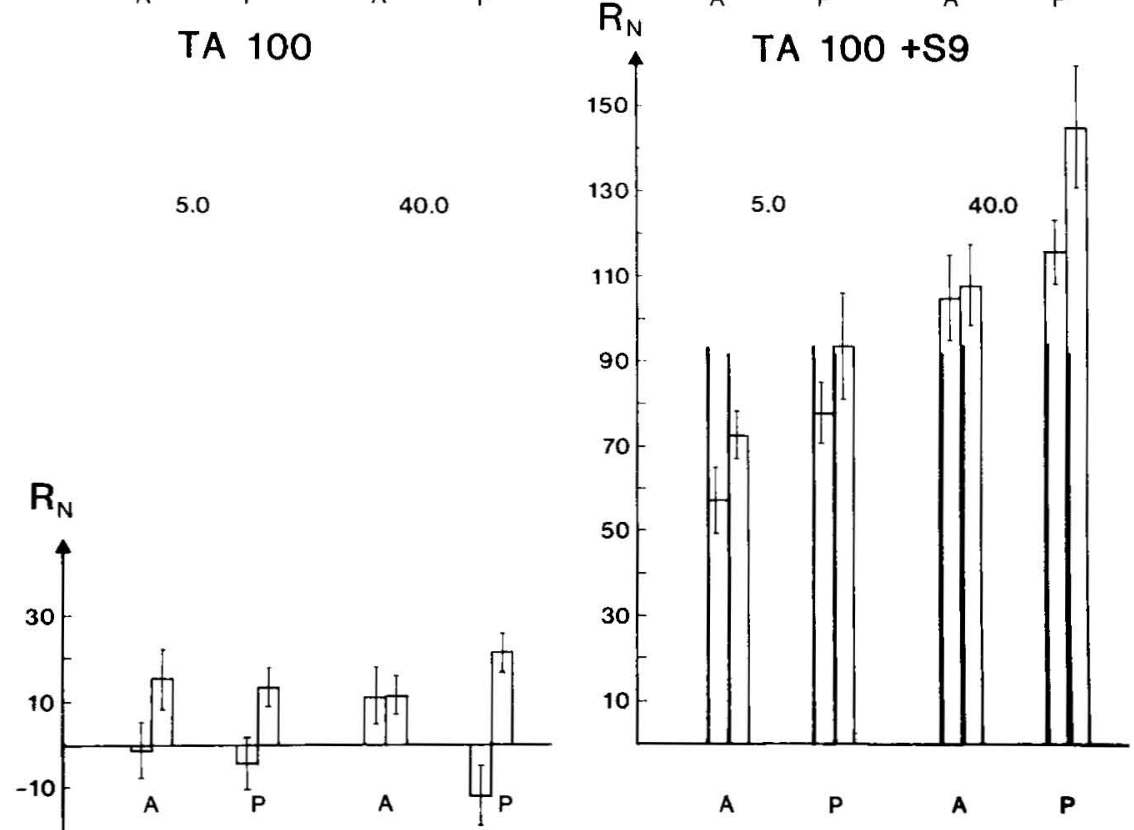

Figure 2. Mutagenic effects of the extracts of airborne particulate matter in 5-I and 40-I samples of air from the anode paste plant (A) and the potroom (P) in two independent experiments. The net response $\left(R_{N}\right)$ is the value obtained after $48 \mathrm{~h}$ of in cubation. Where a tendency for a positive response was found, the corresponding control value of the solvent $R_{K}$ is shown on the left-hand side of the $\mathrm{R}_{\mathrm{N}}$ value. The standard error (SE) values are indicated above each column.

\section{Discussion}

It is assumed that the mutagenicity of the airborne dust is due to adsorbed compounds extracted by organic solvents. These mutagens are mostly indirect and of the type that causes frameshift mutations. This assumption is consistent with the fact that PAH require metabolic activation before they have a muta- genic effect (1) and that they are especially potent for bacterial strains sensitive to frameshift mutations (17).

It should be noted that in the present experiments the extracts were not purified to include only PAH, ie, other mutagens may have been present. The direct mutagenic effect on the TA98 strain may also in- 
dicate that substances other than PAH were present in the extracts.

The air pollution produced by the anode paste plant mainly consisted of volatile PAH (3), which do not show any mutagenic effects with the Ames test (11). These nonmutagenic hydrocarbons may react synergistically however with such mutagens as benzo(a)pyrene (8), which is known to be present at low concentrations in the paste plant atmosphere. The observed effect could thus be a result of synergism between small amounts of mutagenic and larger amounts of nonmutagenic hydrocarbons. The potroom atmosphere also contains some known indirect mutagens. These mutagens, together with nonmutagenic PAH which have a comutagenic effect, may be responsible for the sharp increase in revertants recorded after metabolic activation. The studies performed on samples of expectorate (10) and urine (9) from the workers should to a certain extent help to make the entire study more complete.

There were several difficulties involved in this study of the effects of the work atmosphere in an aluminum plant. The samples were collected on Acropore filters. They therefore contained volatile PAH, or other effective gases, only to a small degree. Only those which are adsorbed on solid particles or are present as liquid drops will thus have been filtered ofi. Ideally only particles equal to or greater than the pore size are filtered off, and the nonparticulate PAH condensates smaller than the pore diameter $(0.8 \mu \mathrm{m})$ and dust particles $<0.8 \mu \mathrm{m}$ in size pass through the filter. The extraction method used will not have eluated all the PAH from the surface of the particles. Only about $20-30 \%$ will have been extracted, and the extraction itself will have been selective (Telnæs, personal communication).

In our tests on air particulate matter, when 5-1 samples of air were analyzed, indirect mutagens were present, and, in 40-1 samples, direct mutagens were also present - essentially those kinds which produce frameshift mutations. The respiratory volume of a resting person is 51 of air/min (16), but this value increases considerably with physical activity. The most important mutagens in the air samples were indirect, but the presence of direct mutagens - especially of the frameshift type - could also be demonstrated.

\section{Acknowledgments}

We wish to thank head physician $T$ Guthe, who initiated the "Lista project," together with head physician JP Lützow-Holm and the Health Service Center at the Lista Aluminium Plant, headed by Dr $H$ Johannesen, for the excellent help received during the collection of the samples. Thanks are also due to the participating workers. We would also like to thank laboratory engineer KM Denstad for his practical assistance.
Financial support was obtained from the Cancer Fund of The University Hospital, Trondheim, Elkem Spigerverket A/S, The Secretariate of Environmental Studies of The Aluminium Industry, and The Electrochemical Employers' Association.

\section{References}

1. Ames BN, Durston WE, Yamasaki E, Lee FD. Carcinogens are mutagens: A simple test system combining liver homogenates for activation+and bacteria for detection. Proc Natl Acad Sci USA 70 (1973) 2281-2285.

2. Ames BN, McCann J, Yamasaki E. Methods for detecting carcinogens and mutagens with the Salmonella mammalian-microsome mutagenicity test. Mutat Res 31 (1975) $347-364$.

3. Bjørseth A, Bjørseth O, Fjeldstad PE. Polycyclic aromatic hydrocarbons in the work atmosphere: I Determination in an aluminum reduction plant. Scand J Work Environ Health 4 (1978) 212-223.

4. Chrisp CE, Fisher GL. Mutagenicity of airborne particles. Mutat Res 76 (1980) 143-164.

5. Chrisp CE, Fisher GL, Lammert JE. Mutagenicity of filtrates from respirable coal fly ash. Science 199 (1978) $73-75$.

6. Doll R. In discussion of the papers by $\mathrm{Mr}$ Andersen, Prof Enterline and Prof Gibbs. In: JP Hughes, ed. Health protection in primary aluminium production: Proceeding of a seminar, Montreal, 22-24 September 1981. Volume 2. International Primary Aluminium Institute, Montreal 1981.

7. Ehrenberg L. Aspects of statistical inference in testing for genetic toxicity. In: BJ Kilbey, M Legator, W Nichols, C Ramel, ed. Handbook of mutagenicity test procedures. Elsevier North-Holland Biomedical Press, Amsterdam, 1979, pp 419-461.

8. Hermann M. Synergistic effects of individual polycyclic aromatic hydrocarbons and the mutagenicity of their mixtures. Mutat Res 90 (1981) 399-409.

9. Krøkje $\AA$, Tiltnes A. Mutagen belastning av luftforurensning $\mathbf{i}$ arbeidsmiljøet ved Lista Aluminiumverk: Støv fra arbeidsatmosfæren, samt ekspectorat og urin fra arbeiderne analysert med Ames' Salmonella typhimurium mutagenesetest [Mutagenic load from occupational air pollution at Lista Aluminium Plant: Dust from air filters, expectorate and urine from exposed workers analyzed by Ames' Salmonella typhimurium mutagen test]. Department of Botany, University of Trondheim, Trondheim 1982.

10. Krøkje Å, Tiltnes A, Mylius E, Gullvảg B. Testing for mutagens in an aluminium plant: The results of Salmonella typhimurium tests on expectorates from exposed workers. Mutat Res 156 (1985) 147-152.

11. McCann J, Choi E, Yamasaki E, Ames BN. Detection of carcinogens as mutagens in Salmonella/microsome test: Assay of 300 chemicals. Proc Natl Acad Sci USA 72 (1975) 5135-5139.

12. Ohsawa M, Ohci T, Hayashi H. Mutagenicity in Salmonella typhimurium mutants of serum extracts from airborne particulates. Mutat Res 116 (1983) 83-90.

13. Serres FJ de, Shelby MD. Meeting report: Recommendations on data production and analysis using the $\mathrm{Sal}$ monella/microsome mutagenicity assay. Mutat Res 159 (1979) 159-165.

14. Takeda N, Teranishi K, Hamada K. Mutagenicity in Salmonella typhimurium TA98 of the serum extract of the organic matter derived from airborne particulates. Mutat Res 117 (1983) 41-46.

15. Tøgersen S, Krohn C, Bjørseth O. Analysemetode for PAH. - Forbedret renseprosedyre. The Foundation 
of Scientific and Industrial Research, Trondheim 1979. (SINTEF-report SFT 21 A79061)

16. Vander AJ, Sherman JH, Luciano DS. Human physiology: The mechanism of body function. McGraw Hill Inc, New York NY, 1975.

17. Venitt S. Bacterial mutation as an indicator of carcinogenicity. Br Med Bull 36 (1980) 57-62.
18. Weinstein D, Lewinson TM. A statistical treatment of the Ames mutagenicity assay. Mutat Res 51 (1978) $433-434$.

Received for publication: 14 February 1984 